\title{
Soils of a medieval burial mound as a paleo- environmental archive (Leningrad region, Northwest Russia)
}

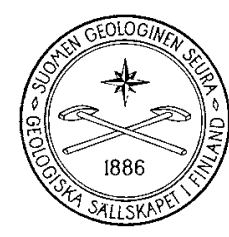

VERTAISARVIOITU KOLLEGIALT GRANSKAD PEER-REVIEWED

\author{
Alexey Rusakov ${ }^{1^{*}}$, Petr Sorokin², Alexandra Golyeva ${ }^{3}$, \\ Larisa Savelieva ${ }^{1}$, Elena Rusakova ${ }^{4}$ and Sergey Safronov ${ }^{1}$ \\ ${ }_{1}$ Saint Petersburg State University, Universitetskaya nab., 7-9, Saint Petersburg, \\ 199034, Russia \\ ${ }^{2}$ Institute of History of Material Culture of the Russian Academy of Sciences, \\ Dvorzovaja nab. 18, Saint Petersburg, 191186, Russia \\ ${ }^{3}$ Institute of Geography of Russian Academy of Sciences, Staromonetny per., 29, \\ Moscow, 119017, Russia \\ ${ }^{4}$ V.V. Dokuchaev Central Soil Science Museum, Birzevoy proezd, 6, Saint Petersburg, \\ 199034, Russia
}

\begin{abstract}
Investigations of the composition of the buried soils formed on the surface of the kame hill (the northwestern part of the East European Plain, Leningrad region) to which the medieval Izhora burial mound was tied showed that the original soil cover was represented by combinations of automorphic Entic (and/or Albic) Podzols (Lamellic, Arenic). These soils are also characteristic of modern biogeocenoses, which indicates a practically changeless trend of pedogenesis in the average time interval. It was determined that during the construction of the mound and leveling of its surface the soil cover was scalped to a significant degree. The diagenetic changes in soils during the time of their burial ( $~ 800$ years) were determined. Based on the data of phytolith and spore-pollen analyses it was shown that the original coniferous forest was cut down, partly burnt. Then the site with ash was plowed for cereal crops. After a short time, when the fertility of the soil had decreased, the site was abandoned and began to overgrow with forest (from small-leaved species to coniferous). At this stage, the forest was rebuilt for burial mounds.
\end{abstract}

Keywords: buried soils, Podzols, Late Holocene, Izhora burial monuments, paleoecological reconstruction, phytolith and spore-pollen analyses.

*Corresponding author (e-mail: spp-06@mail.ru)

Editorial handling: Pertti Sarala (pertti.sarala@gtk.fi) 


\section{Introduction}

The study of the medieval monuments on the territory of the Leningrad region was started in the middle of the $19^{\text {th }}$ century by the archaeologists of the Imperial Archaeological Commission. However, the system of Baltic-Finnish tribes and Slavic population migration has been studied unevenly. The largest arrays of burial mound monuments of the time are known on the territories of the Izhora Plateau (11-15 $5^{\text {th }}$ centuries) and the southeastern shore of the Ladoga Lake (9-13 ${ }^{\text {th }}$ centuries). The ground Karelian burials in the northwestern shore of the Ladoga Lake (12-14 th $^{\text {th }}$ century) are less studied. Burial monuments associated with Izhora discovered in the last decades remain the least studied. The biggest interest lies in a group of burial monuments discovered in 2006, 2009, and 2012 in the watershed territory of the Mga River (left tributary of the Neva River) in the vicinity of the villages Kirsino - Shapki (Fig 1a). The area of archaeological objects is located about $20 \mathrm{~km}$ from Neva River (Sorokin 2006, 2008). The $12-13^{\text {th }}$-century Izhora burials studied to date were inhumations on the surface, as well as, possibly, in shallow graves. They were surrounded by stone fencings covered with low mounds. The territory was prepared for burial through vegetation burning and surface leveling by means of adding earth.

The Kirsino 8 mound had dimensions of approximately $15 \times 15 \mathrm{~m}$ and a height of $1.2 \mathrm{~m}$. It was made on a natural slope (Fig. 1b, c). The excavations on the area of $226 \mathrm{~m}^{2}$ revealed 8 stone fences of boulders with size of 0.1-0.9 m. Inside the fences the 11 burials with clothing inventory including jewelry, household items, pottery, and weapons were studied (Fig. 1d). The stone structures were covered with a layer of brown sand.

The objective of this article is to study the buried soils under the $12-13^{\text {th }}$-century burial mounds of the Mga River watershed territory (Leningrad region) using a variety of methods to perform a paleoecological reconstruction of the landscape and determine the nature of the original surface and vegetative cover. The study of buried soils on dated surfaces will allow for the evaluation of the degrees of changes in the morphological structure and soil properties in the second half of the Subatlantic period of the Holocene in the sequence: buried soil - newly-formed soil on mounds - surface soil.

\section{Study area}

The Kirsino 8 settlement is situated in the northwestern part of the East European Plain $54 \mathrm{~km}$ southeast of the city Saint Petersburg (Fig. 1a). According to the soil-ecological zonation of Russia (Shishov et al., 2001), the study area belongs to the northern part of the Chudsko-Ladoga province dominated by Retisols and Podzols (according to the classification of the IUSS working group WRB, 2015) developed under southern taiga forests. A forest with a domination of pine spruce with an admixture of small-leaved species, which is typical for zonal representatives of forest landscapes of the southern taiga of the northwest of Eastern Europe (Fig. 2b), grows within the investigated area.

The study area is represented by an accumulative lacustrine-glacial plain. The flat, monotonous relief of the plain is complicated by the presence of kame hills. The settlement is situated on a flattened surface of a separate kame hill (Fig 1b), elevated at $-55 \mathrm{~m}$ a.s.l. The climate of the examined region is transitional, from moderately continental to moderately maritime. The mean annual temperature in the studied area is $+3.6^{\circ} \mathrm{C}$. The mean annual precipitation is $-600 \mathrm{~mm}$, and the value of the precipitation/evapotranspiration ratio is 1.33 .

\section{Materials and methods}

The objects of our study are soils buried by burial mound layers as a result of burial site construction at the end of the 12th-early 13 th centuries. The four buried soil profiles (profiles K1-K4) were studied (Fig. 2) in order to retrieve environmental trends. It is important to note that both, the buried soil profiles themselves and their fragments, preserved 

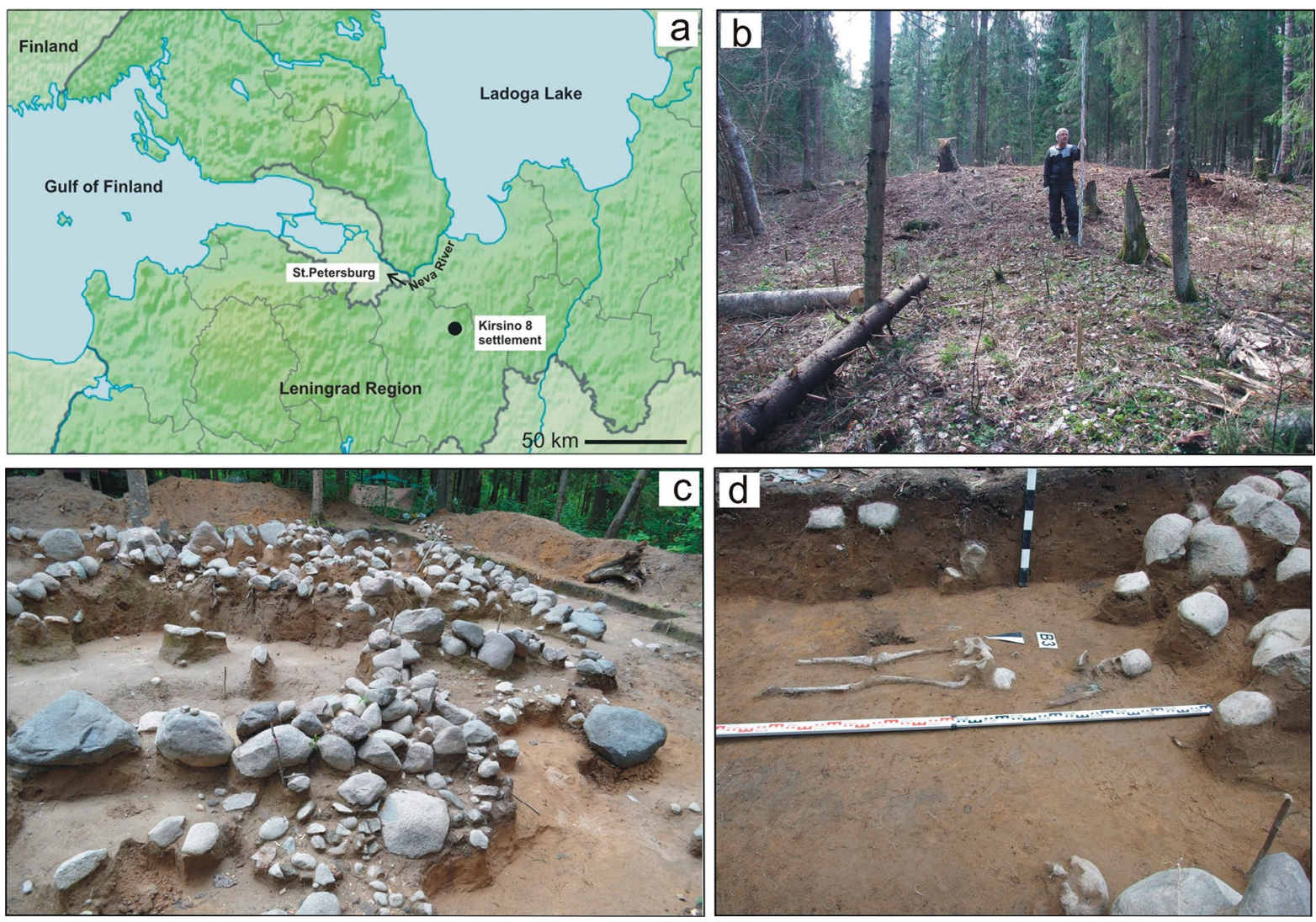

Figure 1. The Kirsino 8 archaeological settlement: a) Geographical location of the study site; b) A separate kame hill, to the surface of which the archaeological settlement is confined; c) General view of the settlement. Note the places of graves surrounded by stone fencings; d) The burial place on a top of well-preserved buried soil.

to varying degrees, and the layers of the barrow mound that overlapped them, were chosen for this study. The profiles are located in close proximity to each other - no more than $8 \mathrm{~m}$ from the central part of the burial mound (where the thickness of the bulk layer is $-1.1 \mathrm{~m}$ ) to its edge part. In the buried soils in the K2-K4 profiles, Humic horizons of virgin soils are diagnosed. Only the profile K1, which is restricted to the central part of the burial mound, is represented by soil-forming rock (Fig. 2). To retrieve environmental trends the surface soil (profile K5), which formed on both the same surface and lithology and at approximately the same hypsometric level, was studied (Fig. 2).

The surface and buried soils have been examined morphologically according to the FAO Guidelines for Soil Description (2006). Field identification of soils was determined using the IUSS Working Group WRB (2015). Grain size analysis for fine earth material $(<1 \mathrm{~mm})$ was done using the conventional pipette method (Kachinskiy, 1965) to appropriate texture classes. Particle size distribution was analyzed for Russian conventional fraction groups (Table 1). Textural classes were determined according to the FAO Guidelines for Soil Description (2006). Organic matter, $\mathrm{pH}$ and TOC were analyzed using conventional methods for soils of the forest zone (Kozlovskiy, 1977; Vorobyova, 2006).

Microbiomorphic analysis involved a consecutive study of the different types of biomorphs under a microscope (Golyeva, 2001). Fifty-gram samples were treated with a $30 \%$ solution of hydrogen peroxide and then separated from quartz 


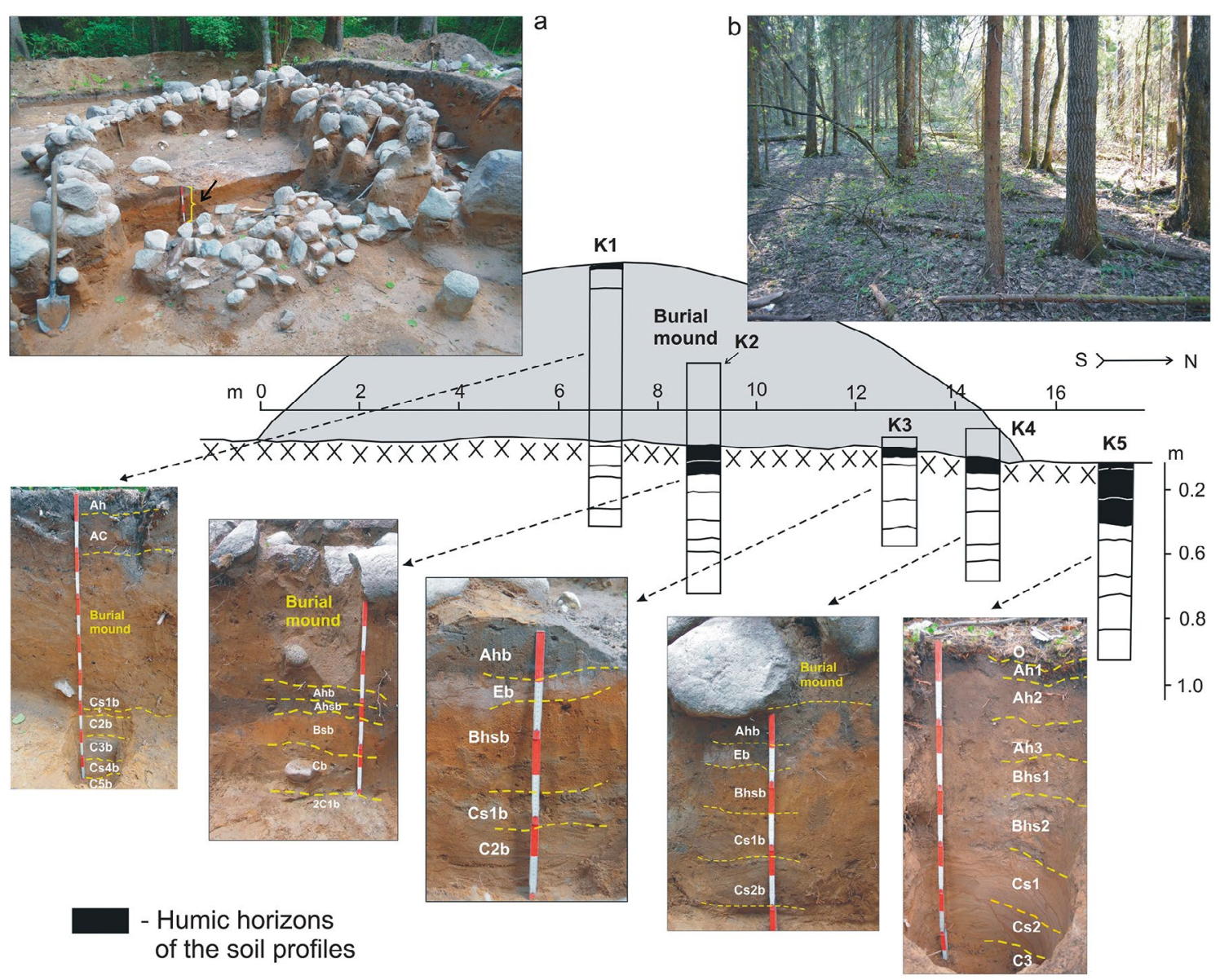

Figure 2. The Kirsino 8 settlement and the buried (K1-K4) and surface (K5) soil profiles within investigated site. a) General view of the settlement. Note the profile of buried soil (marked by arrow); b) A forest with a domination of pine spruce with an admixture of small-leaved species within the settlement area.

and other mineral grains by flotation in a heavy liquid, a mixed cadmium iodide and potassium iodide solution with a specific gravity of 2.3. After centrifugation, the floating siliceous and organic microbiomorphs were collected and washed several times with distilled water, then immersed in oils (glycerin) for study with an optical microscope at magnifications ranging from $200 x$ to $900 x$. The entire complex of microbiomorphs was identified and counted. Quantitative assessment allows comparisons of their distribution between samples. Analyses of biomorphs included a phytolith complex, plant remains and charcoal (Golyeva, 2007).

Pollen extraction from the buried soils were performed in accordance with Grischuk's separation method (Grichuk \& Zaklinskaya, 1948). In addition, 7-mm ultrasonic fine-sieving was used for all samples (Cwynar et al., 1979). Pollen and spore identification was carried out using published sources (Kupriyanova \& Alyoshina, 1972, 1978; Moore et al., 1991) and reference collections at the Saint Petersburg State University. 
Table 1. Grain size distribution (pipette method) and some chemical properties in the studied soils.

\begin{tabular}{|c|c|c|c|c|c|c|c|c|c|c|}
\hline \multirow[b]{2}{*}{ Horizon } & \multirow{2}{*}{$\begin{array}{l}\text { Depth, } \\
\mathrm{cm}\end{array}$} & \multicolumn{6}{|c|}{ Particle size $(\mathrm{mm})$ distribution * } & \multirow{2}{*}{$\begin{array}{c}\text { Textural classes } \\
\text { (FAO Guidlines } \\
\text { 2006) }\end{array}$} & \multirow[b]{2}{*}{$\mathrm{pH}_{\text {water }}$} & \multirow[b]{2}{*}{$\begin{array}{l}\text { TOC, } \\
g / 100 \mathrm{~g}\end{array}$} \\
\hline & & $\begin{array}{c}\text { MS } \\
1-0.25\end{array}$ & $\begin{array}{c}\text { FS } \\
0.25- \\
0.05\end{array}$ & $\begin{array}{c}\text { CSi } \\
0.05- \\
0.01\end{array}$ & $\begin{array}{c}\text { MSi } \\
0.01- \\
0.005\end{array}$ & $\begin{array}{c}\text { FSi } \\
0.005- \\
0.001\end{array}$ & $\begin{array}{c}C \\
<0.001\end{array}$ & & & \\
\hline \multicolumn{11}{|c|}{ Profile K1. Surface soil: Protic Arenosol (Novic) } \\
\hline Ah & $0-6$ & 37 & 36 & 11 & 6 & 5 & 5 & SL & 3.54 & 3.59 \\
\hline \multirow[t]{4}{*}{ AC } & $6-15$ & 47 & 31 & 8 & 7 & 4 & 3 & LS & 3.31 & 1.69 \\
\hline & $15-20$ & 11 & 49 & 13 & 11 & 10 & 6 & SL & 3.26 & 1.26 \\
\hline & $25-35$ & 38 & 34 & 10 & 7 & 7 & 4 & SL & 3.33 & 0.55 \\
\hline & $35-40$ & 39 & 34 & 9 & 7 & 6 & 5 & SL & 3.47 & 1.22 \\
\hline Material of & $40-55$ & 39 & 34 & 10 & 7 & 6 & 4 & SL & 3.92 & 0.57 \\
\hline \multirow[t]{4}{*}{ burial mound } & $55-65$ & 42 & 33 & 8 & 7 & 6 & 4 & SL & 3.68 & 0.47 \\
\hline & $65-80$ & 43 & 30 & 9 & 7 & 7 & 4 & SL & 3.70 & 0.43 \\
\hline & $80-95$ & 37 & 35 & 10 & 8 & 6 & 4 & SL & 3.80 & 0.34 \\
\hline & $95-110$ & 41 & 34 & 9 & 6 & 6 & 4 & SL & 3.76 & 0.43 \\
\hline Cs1b & $110-115$ & 46 & 30 & 10 & 6 & 3 & 5 & LS & 3.83 & 0.38 \\
\hline $\mathrm{C} 2 \mathrm{~b}$ & $115-125$ & 50 & 37 & 4 & 4 & 2 & 3 & LS & 3.90 & 0.26 \\
\hline C3b & $125-132$ & 54 & 33 & 4 & 4 & 2 & 3 & LS & 3.81 & 0.22 \\
\hline Cs4b & $132-150$ & 56 & 25 & 7 & 5 & 4 & 3 & LS & 3.78 & 0.12 \\
\hline $\mathrm{C} 5 \mathrm{~b}$ & $150-160$ & 55 & 41 & 1 & 1 & 1 & 1 & $\mathrm{~S}$ & 3.95 & 0.12 \\
\hline \multicolumn{11}{|c|}{ Profile K2. Buried soil: Entic Podzol (Lamellic, Arenic) } \\
\hline & $0-10$ & 45 & 37 & 9 & 4 & 3 & 2 & LS & 3.83 & 0.07 \\
\hline Material of & $10-20$ & 46 & 36 & 9 & 4 & 3 & 2 & LS & 3.84 & 0.03 \\
\hline \multirow[t]{2}{*}{ burial mound } & $20-35$ & 54 & 30 & 8 & 5 & 2 & 1 & LS & 3.85 & 0.03 \\
\hline & $40-50$ & 48 & 28 & 12 & 6 & 4 & 2 & LS & 3.92 & 0.03 \\
\hline Ahb & $51-58$ & 47 & 26 & 13 & 7 & 5 & 2 & SL & 4.19 & 0.05 \\
\hline Ahsb & $58-65$ & 54 & 28 & 9 & 5 & 3 & 1 & LS & 4.50 & 0.03 \\
\hline Bsb & $65-72$ & 54 & 30 & 7 & 4 & 3 & 2 & LS & 4.74 & 0.03 \\
\hline $\mathrm{Cb}$ & $72-85$ & 57 & 32 & 5 & 3 & 2 & 1 & LS & 4.78 & 0.02 \\
\hline \multirow{2}{*}{$2 \mathrm{C} 1 \mathrm{~b}$} & $85-95$ & 12 & 0 & 29 & 24 & 25 & 10 & SiL & 4.27 & 0.03 \\
\hline & $95-105$ & 24 & 0 & 27 & 20 & 21 & 8 & SiL & 4.11 & 0.03 \\
\hline $2 \mathrm{c} 2 \mathrm{~b}$ & $105-115$ & 75 & 18 & 2 & 2 & 2 & 1 & $S$ & 4.51 & 0.02 \\
\hline \multirow{2}{*}{$3 c 3 b$} & $115-130$ & 77 & 20 & 1 & 1 & 1 & 0 & $\mathrm{~S}$ & 4.65 & 0.02 \\
\hline & $130-140$ & 76 & 20 & 2 & 1 & 1 & 0 & $\mathrm{~S}$ & 4.50 & 0.02 \\
\hline \multicolumn{11}{|c|}{ Profile K3. Buried soil: Albic Podzol (Lamellic, Arenic) } \\
\hline $\begin{array}{c}\text { Material of } \\
\text { burial mound }\end{array}$ & $0-5$ & 41 & 37 & 9 & 6 & 5 & 2 & LS & 3.52 & 1.29 \\
\hline Ahb & $5-10$ & 43 & 41 & 8 & 2 & 4 & 2 & LS & 3.51 & 0.50 \\
\hline $\mathrm{Eb}$ & $10-15$ & 53 & 36 & 5 & 2 & 3 & 1 & LS & 3.55 & 0.34 \\
\hline & $15-25$ & 45 & 39 & 5 & 6 & 4 & 1 & LS & 3.40 & 0.43 \\
\hline Bhsb & $25-35$ & 42 & 37 & 7 & 6 & 5 & 3 & LS & 3.48 & 1.02 \\
\hline Cs1b & $35-50$ & 52 & 36 & 4 & 3 & 3 & 2 & LS & 4.03 & 0.52 \\
\hline $\mathrm{C} 2 \mathrm{~b}$ & $50-60$ & 67 & 27 & 2 & 1 & 2 & 1 & $\mathrm{~S}$ & 4.65 & 0.12 \\
\hline Profile & K4. Burieds & il: Albic Po & Izol (Lam & llic, Are & & & & & & \\
\hline Material of & & & & & & & & & & \\
\hline burial mound & $0-20$ & 45 & 30 & 9 & 7 & 6 & 3 & $S L$ & 3.47 & 0.41 \\
\hline Ahb & $20-30$ & 41 & 32 & 7 & 10 & 8 & 2 & SL & 3.71 & 0.74 \\
\hline $\mathrm{Eb}$ & $30-40$ & 59 & 30 & 4 & 3 & 3 & 1 & LS & 3.80 & 0.21 \\
\hline Bhsb & $40-50$ & 53 & 29 & 7 & 5 & 5 & 1 & LS & 4.05 & 0.31 \\
\hline Cs1b & $50-60$ & 66 & 26 & 3 & 2 & 2 & 1 & $\mathrm{~S}$ & 4.06 & 0.22 \\
\hline & $60-70$ & 61 & 30 & 3 & 2 & 3 & 1 & $\mathrm{~S}$ & 4.24 & 0.21 \\
\hline $\mathrm{Cs} 2 \mathrm{~b}$ & $70-80$ & 60 & 33 & 2 & 2 & 2 & 1 & $\mathrm{~S}$ & 4.33 & 0.21 \\
\hline Cs3b & $80-90$ & 83 & 13 & 1 & 1 & 1 & 1 & $\mathrm{~S}$ & 4.30 & 0.17 \\
\hline Profile & K5. Surface & soil: Entic & odzol (La & ellic, $\mathrm{Ar}$ & & & & & & \\
\hline Ahb1 & $0-4$ & 36 & 31 & 18 & 5 & 6 & 4 & $\mathrm{SL}$ & 3.57 & 6.26 \\
\hline Ahb2 & $4-20$ & 36 & 32 & 17 & 8 & 6 & 1 & SL & 3.46 & 2.31 \\
\hline Ahb3 & $20-35$ & 37 & 26 & 16 & 10 & 8 & 3 & SL & 3.50 & 0.95 \\
\hline Bhsb1 & $35-45$ & 32 & 22 & 22 & 12 & 9 & 3 & SL & 3.56 & 0.79 \\
\hline Bhsb2 & $52-74$ & 42 & 28 & 13 & 9 & 6 & 2 & SL & 3.53 & 0.50 \\
\hline Cs1 & $80-90$ & 72 & 24 & 1 & 1 & 1 & 1 & $S$ & 4.15 & 0.07 \\
\hline Cs2 & $95-110$ & 0 & 81 & 7 & 4 & 2 & 6 & SL & 4.26 & 0.12 \\
\hline C3 & $113-130$ & 4 & 80 & 7 & 4 & 2 & 3 & LS & 4.52 & 0.07 \\
\hline
\end{tabular}

* MS - medium sand; FS - fine sand; Csi - coarse silt; MSi - medium silt; Fsi - fine silt; C - clay. Textural classes (IUSS.... 2006): S - Sand; LS - Loamy sand; SL - Sandy loam; SiL - silt loam. 


\section{Results and discussion}

The buried soils within the archaeological site Kirsino were spread sporadically. Parent material which partly scalped is revealed under the burial mound and represented by water-glacial (kame) sands and sandy loams, in some cases underlain by moraine loams. All this makes it difficult to reconstruct the component composition of the soil cover when reconstructing the original landscape conditions.

The two buried soils (the profiles $\mathrm{K} 3$ and K4) were classified as Albic Podzols (Lamellic, Arenic) and formed on kame sands. These soils have the following set of genetic horizons, which is typical for Podsols developed on sandy parent material under south taiga vegetation: Ahb-Eb-Bhsb$\mathrm{Cs} 1 \mathrm{~b}-\mathrm{C}(\mathrm{s}) 2 \mathrm{~b}-\mathrm{Cs} 3 \mathrm{~b}$. The thickness of the Humic horizon in the profiles varies from $-3 \mathrm{~cm}$ (profile $\mathrm{K} 3)$ to $10(12) \mathrm{cm}$ (profile K4). There is a presence of bleached albic material located under the Humic horizons in the profiles of these soils. The Spodic Bhsb horizons of the soils are characterized by an accumulation of blackish organic matter and reddish Fe oxides. The third buried soil (profile K3) was classified as an Entic Podzol (Lamellic, Arenic) (with a set of horizons Ahb-Ahsb-Bsb-Cb-2C1b$2 \mathrm{C} 2 \mathrm{~b}-3 \mathrm{C} 3 \mathrm{~b}$ ), which distinguished it from profiles $\mathrm{K} 3$ and $\mathrm{K} 4$ by the absence of albic material in the structure of the profile. The thicknesses of the two Humic horizons of the soil are $-14 \mathrm{~cm}$. The soil formed in the top layer of the burial mound and restricted to the highest flat surface of the mound was classified as a Protic Arenosol (Novic) and has the profile Ah-AC, with a thickness of $6 \mathrm{~cm}$ in the Ah horizon. The surface soil of the chronosequence (profile K5), - Entic Podzol (Lamellic, Arenic), - is morphologically close to profile K2 but is characterized by relatively thick Humic horizons $(35 \mathrm{~cm})$.

An important diagnostic morphological feature of the studied buried soils and parent material (with the exception of profile K3) is the presence of nonconcretionary new Fe formations, represented by pseudofibres (lamellas) which reflect intrahorizon migration and segregated accumulation of $\mathrm{Fe}$ oxides. Iron lamellae are non-cemented bands of illuvial iron $<2.5 \mathrm{~cm}$ thick and reflect seasonal changes in groundwater level. In all investigated buried soil profiles of buried soils there are inclusions of charcoal fragments of different sizes, the content of which varies by volume from 2 to $10 \%$. We noted that the inclusion of charcoal fragments was observed only in the allochthonous material of the burial mound and the preserved Humic horizons of the buried soils. We can assume that 1) only the upper part of the soil cover under the construction of the burial mound (profiles K2-K4) was affected by anthropogenic influence or 2) the soil profile was completely cut off within the central, initially relatively high part of the kame hill (profile K1).

The grain size distribution pattern is in good agreement with the morphological observations. All studied buried soils are formed in loamy sand and sand sediments (Table 1), with medium and fine sands fractions significantly predominating. One exception can be observed in the $\mathrm{K} 2$ profile, in which, at a depth of $85-105 \mathrm{~cm}$, there is a presence of a silt loamy interlayer. The surface soil, unlike buried soils, is characterized by sandy loam texture in the upper $0-70 \mathrm{~cm}$, whereas the basal part is sand to loamy sand in texture. The earth material of the burial mound is similar in granulometric composition to the material of the surface soil (Table 1), suggesting that the upper and middle parts of the previous soil profiles have been taken from the nearest surroundings during the burial mound construction. This is proven particularly clearly by the textural change of the allochthonous layers and the original parent material in the profile $\mathrm{K} 1$.

All horizons of buried and surface soils as well as the material of the burial mound are mostly strongly acidic (Table 1), which is typical for the Podzols of south taiga areas of the East European Plain. Humus content is relatively high in the upper Humic horizon of the surface soil (profile K5) and less high in the Ah horizon of the Protic Arenosol (Novic) formed in the upper layer of the burial mound (Table 1). Humus content in the buried 
Table 2. Semiquantative content of different types of microbiomorphs of the studied soils.

\begin{tabular}{|c|c|c|c|c|c|}
\hline \multirow[t]{2}{*}{ Horizon } & \multirow[t]{2}{*}{ Depth,cm } & \multirow{2}{*}{$\begin{array}{c}\text { Non-siliceous vegetable indicators } \\
\text { Detritus }^{1}\end{array}$} & \multicolumn{2}{|c|}{ Siliceous non-vegetable indicators } & \multirow{2}{*}{$\begin{array}{c}\text { Plant silica } \\
\text { Phytolith }^{1} \\
\end{array}$} \\
\hline & & & Sponge spicules $^{1}$ & Diatoms $^{1}$ & \\
\hline \multicolumn{6}{|c|}{ Profile K1. Surface soil: Protic Arenosol (Novic) } \\
\hline Ah, & $0-6$ & +++ & Single & - & + \\
\hline $\mathrm{AC}$ & $6-10$ & +++ & - & - & + \\
\hline \multirow[t]{2}{*}{ Material of burial mound } & $100-05$ & +++ & - & - & + \\
\hline & $105-110$ & ++ & - & - & + \\
\hline Cs1b & $110-115$ & + & - & - & Single \\
\hline $\mathrm{C} 2 \mathrm{~b}$ & $115-120$ & Single & - & Single & - \\
\hline \multicolumn{6}{|c|}{ Profile K2. Buried soil: Entic Podzol (Lamellic, Arenic) } \\
\hline Ahb & $50-53$ & +++ & Single & - & + \\
\hline Ahb & $53-58$ & +++ & - & - & + \\
\hline \multirow[t]{2}{*}{ Ahsb } & $58-63$ & +++ & Single & - & + \\
\hline & $63-65$ & ++ & - & - & + \\
\hline Bsb & $65-72$ & + & Single & - & + \\
\hline \multicolumn{6}{|c|}{ Profile K3. Buried soil: Albic Podzol (Lamellic, Arenic) } \\
\hline Material of burial mound & $0-5$ & +++ & Single & - & + \\
\hline Ahb & $5-10$ & +++ & Single & - & + \\
\hline $\mathrm{Eb}$ & $10-15$ & + & - & - & + \\
\hline Bhsb & $15-20$ & Single & - & - & - \\
\hline \multicolumn{6}{|c|}{ Profile K4. Buried soil: Albic Podzol (Lamellic, Arenic) } \\
\hline \multirow[t]{2}{*}{ Material of burial mound } & $10-15$ & +++ & Single & - & + \\
\hline & $15-20$ & +++ & - & - & Single \\
\hline \multirow[t]{2}{*}{ Ahb } & $20-25$ & +++ & - & Single & ++ \\
\hline & $25-30$ & +++ & Single & - & + \\
\hline \multirow[t]{2}{*}{$\mathrm{Eb}$} & $30-35$ & +++ & - & - & + \\
\hline & $35-40$ & ++ & Single & - & + \\
\hline Bhsb & $40-45$ & + & - & - & - \\
\hline
\end{tabular}

1+++ (many): over 100 units; ++ (middle): 40-100 units; + (little): 5-40 units; Single: 1 - units; (absent): -

soil is much lower than in the surface soils and varies between $0.03-0.05 \%$ in profile $\mathrm{K} 2$ and $0.5-$ $0.74 \%$ in profiles $\mathrm{K} 3$ and $\mathrm{K} 4$. We can assume that this decrease of TOC is the result of diagenesis. We consider diagenesis a set for all chemical, physical, and biological processes that change sediments and soils after burial beneath younger deposits (Paleopedology Glossary, 1994).

The most informative among the components of microbiomorphic analysis are the results of the phytolith analysis, which has long and effectively proved itself of value in our work with buried soils (Engovatova \& Golyeva, 2012; Golyeva \& Aleksandrovskiy, 1999; Golyeva et al., 1995). All the soil samples contain a small and very small amount of phytoliths (Table 2). This is typical for sandy soils, but, importantly, the upper horizons of the surface or buried soils should contain more phytoliths than the lower horizons of the same soil. But this rule was not observed to hold in almost any profile, which indicates erosion process of the soil cover before its burial. This means that during the planning of the surface during construction of the mound, the upper horizons of the soils, had been totally (Litter horizon) or partly (Humic horizon) scalped. We can observe the frequent or regular occurrence of spicules of sponges and shells of diatoms within the studied soil profiles. This may indicate ancient alluvial genesis of the deposits.

A small amount of phytoliths does not allow to confidently reconstruct the history of the landscape, especially taking into account the disturbance of soil profiles (profiles K1 and K2). Profile K4 (Table 3) is the most informative. In the upper horizon of this soil profile, the greatest number of phytoliths between all samples was found. This is the only 
a

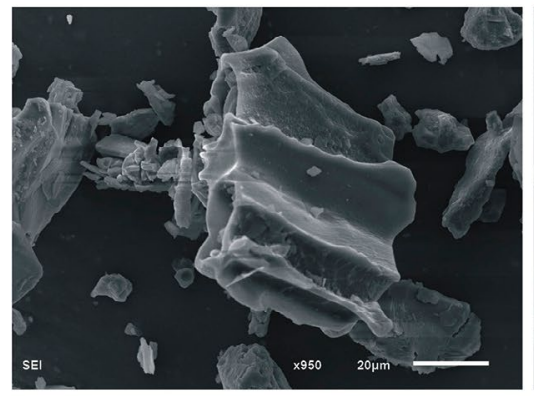

d

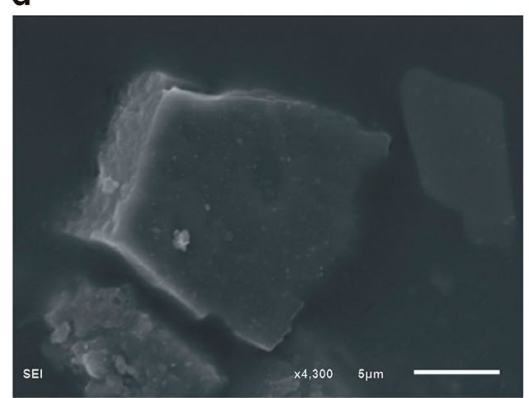

g

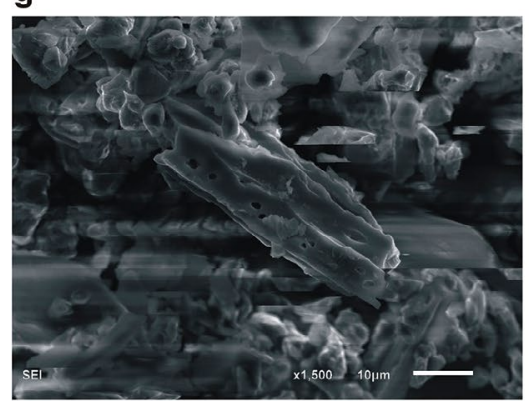

b

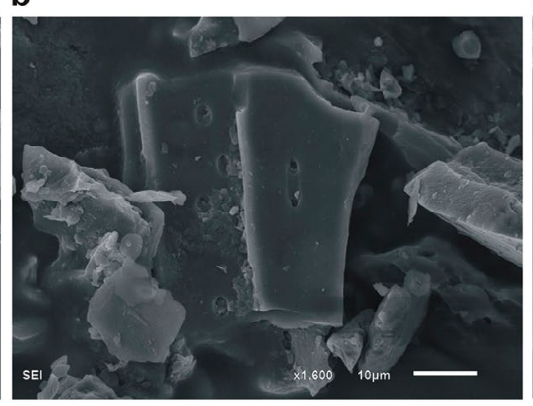

e

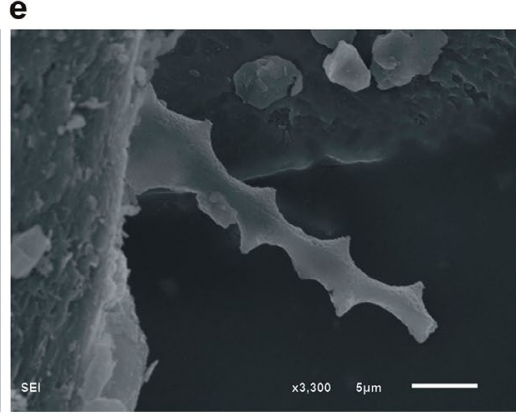

h

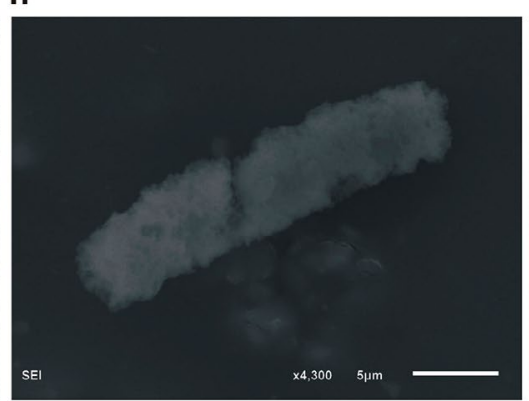

C

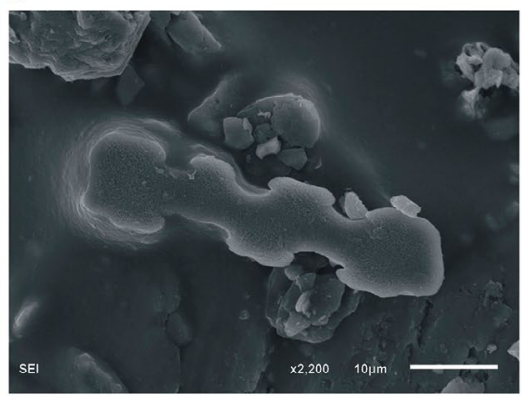

f

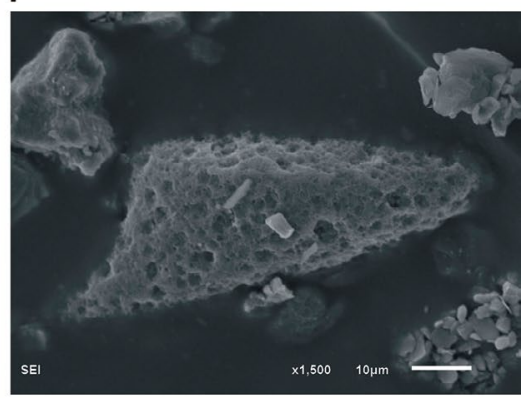

i

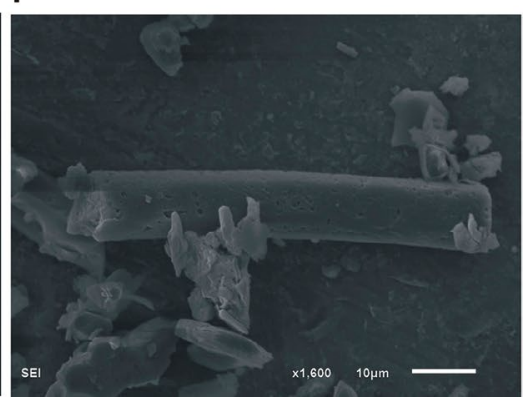

Figure 3. Silica microbiomorphs and phytoliths from profile K4. The buried soil: Albic Podzol (Lamellic, Arenic). The Agb horizon (depth of 20-25 cm): a, b) wood detritus; c) n-lobate form from meadow grasses; d) parallel-epipedal rectangle scrobiculate form from coniferous; e) dendritic form from cultural cereals; f) corroded carinate lanceolate form from broad-leave forest grasses. The Agb horizon (depth of 25-30 cm): g) wood detritus; h) corroded elongated form from herbs; i) elongated form.

sample from the Ahb horizon of the studied soils, in which a phytolith of cultivated cereals was identified (Fig. 3). The presence of a phytolith of a cultural cereal allows to assume, that this site was earlier plowed up.

The content and distribution of phytoliths in the underlying samples of the K4 profile correspond to the normal distribution in soils. Because there are forms typical for the coniferous species in the sample 35-40 cm (the Eb horizon), we can assume that originally a coniferous forest had grown in this place. Later conifers were cut down. Perhaps this period is associated with the initial (most intensive?) period of development of the site. The next stage of anthropogenesis was arable (cultivated grain crops) and we found phytoliths from cultivated cereals (Table 3, Fig. 3). Subsequently, the intensity of human habitation of this area decreased, and immediately before burial surface, a broad-leaved forest began to overgrow the site. We can conclude it because of the high percent of conifers in the upper burial horizon (Table 3). 
Table 3. Silica microbiomorphs (unit/\%) and distribution of phytoliths forms (\%) of the studied soils.

\begin{tabular}{|c|c|c|c|c|c|c|c|c|c|c|c|c|c|c|}
\hline \multirow[t]{2}{*}{ Horizon, } & \multirow[t]{2}{*}{ Depth, cm } & \multirow[t]{2}{*}{ Total } & \multirow{2}{*}{$\begin{array}{l}\text { Spicules } \\
\text { //Diatoms }\end{array}$} & \multirow[t]{2}{*}{ Phytoliths total } & \multicolumn{10}{|c|}{ Phytolith distribution } \\
\hline & & & & & $1^{1}$ & $2^{1}$ & $3^{1}$ & $4^{1}$ & $5^{1}$ & $6^{1}$ & $7^{1}$ & $8^{1}$ & $9^{1}$ & $10^{1}$ \\
\hline \multicolumn{15}{|c|}{ Profile K1. Surface soil: Protic Arenosol (Novic) } \\
\hline Ah, & $0-6$ & $36 / 100$ & $2 / 6 / /-$ & $34 / 94$ & 38 & 15 & 18 & 26 & - & - & - & - & 3 & - \\
\hline $\mathrm{AC}$ & $6-10$ & $6 / 100$ & - & $6 / 100$ & 66 & - & - & 17 & - & - & 17 & - & - & - \\
\hline \multirow{2}{*}{$\begin{array}{l}\text { Material of burial } \\
\text { mound }\end{array}$} & $100-05$ & $4 / 100$ & - & $4 / 100$ & 75 & - & - & 25 & - & - & - & - & - & - \\
\hline & $105-110$ & $5 / 100$ & - & $5 / 100$ & 40 & 20 & 20 & 20 & - & - & - & - & - & - \\
\hline Cs1b & $110-115$ & $1 / 100$ & - & $1 / 100$ & 100 & - & - & - & - & - & - & - & - & - \\
\hline $\mathrm{C} 2 \mathrm{~b}$ & $115-120$ & $1 / 100$ & $\begin{array}{c}-/ / \\
1 / 100\end{array}$ & - & - & - & - & - & - & - & - & - & - & - \\
\hline \multicolumn{15}{|c|}{ Profile K2. Buried soil: Entic Podzol (Lamellic, Arenic) } \\
\hline Ahb & $50-53$ & $11 / 100$ & $1 / 9 / /-$ & $10 / 91$ & 80 & - & - & 20 & - & - & - & - & - & - \\
\hline Ahb & $53-58$ & $7 / 100$ & - & $7 / 100$ & 43 & - & - & - & - & - & - & - & 57 & - \\
\hline \multirow[t]{2}{*}{ Ahsb } & $58-63$ & $6 / 100$ & $2 / 33 / /-$ & $4 / 67$ & 50 & 50 & - & - & - & - & - & - & - & - \\
\hline & $63-65$ & $10 / 100$ & - & $10 / 100$ & 10 & 20 & 20 & 50 & - & - & - & - & - & - \\
\hline Bsb & $65-72$ & $5 / 100$ & $1 / 20 / /-$ & 4/80 & 50 & 50 & - & - & - & - & - & - & - & - \\
\hline \multicolumn{15}{|c|}{ Profile K3. Buried soil: Albic Podzol (Lamellic, Arenic) } \\
\hline $\begin{array}{l}\text { Material of burial } \\
\text { mound }\end{array}$ & $0-5$ & $17 / 100$ & $1 / 6 / /-$ & $16 / 94$ & 70 & 6 & 12 & 12 & - & - & - & - & - & - \\
\hline Ahb & $5-10$ & $17 / 100$ & $3 / 18 / /-$ & $14 / 82$ & 42 & - & 22 & 22 & - & - & - & - & 14 & - \\
\hline $\mathrm{Eb}$ & $10-15$ & $5 / 100$ & - & $5 / 100$ & 40 & - & - & 40 & - & - & - & - & 20 & - \\
\hline Bhsb & $15-20$ & - & - & - & - & - & - & - & - & - & - & - & - & - \\
\hline \multicolumn{15}{|c|}{ Profile K4. Buried soil: Albic Podzol (Lamellic, Arenic) } \\
\hline \multirow{2}{*}{$\begin{array}{l}\text { Material of burial } \\
\text { mound }\end{array}$} & $10-15$ & $14 / 100$ & $1 / 7 / /-$ & $13 / 93$ & 31 & 15 & 8 & 31 & - & - & - & - & 15 & - \\
\hline & $15-20$ & $1 / 100$ & - & $1 / 100$ & - & - & - & - & - & - & - & - & 100 & - \\
\hline \multirow[t]{2}{*}{ Ahb } & $20-25$ & $45 / 100$ & $-/ / 1 / 2$ & $44 / 98$ & 27 & 20 & - & 20 & 4 & 7 & 4 & - & 4 & 14 \\
\hline & $25-30$ & $18 / 100$ & $1 / 5 / /-$ & $17 / 95$ & 35 & 6 & 12 & 41 & - & - & - & - & 6 & - \\
\hline \multirow[t]{2}{*}{$\mathrm{Eb}$} & $30-35$ & $9 / 100$ & - & $9 / 100$ & 34 & - & 22 & 22 & - & - & - & - & 22 & - \\
\hline & $35-40$ & $7 / 10$ & $1 / 14 / /-$ & $7 / 86$ & 49 & 17 & - & - & - & - & - & 17 & 17 & - \\
\hline Bhsb & $40-45$ & - & - & - & - & - & - & - & - & - & - & - & - & - \\
\hline
\end{tabular}

The twelve samples of profile K4 were studied using the spore-pollen analysis method. The saturation of microfossil deposits is very low, which is not sufficient for statistical processing and the construction of a spore-pollen diagram. The vast majority of fossil microfossils is poorly preserved: they are crumpled, torn, mineralized, and corroded.

In the spore-pollen spectra at the depth interval from 20 to $30 \mathrm{~cm}$ (the Ahb horizon) absolute dominance belongs to spores of ferns (Polypodiaceae), sphagnum mosses (Sphagnum), and lycopodium (Lycopodium clavatum, L.annotinum). Herbaceous plants are represented mainly by the pollen of chicory (Cichoriaceae) and onagraceae (Onagraceae). There is also a presence of the pollen of the sedge and cereals families. Only one strongly crushed pollen grain from a group of cultivated cereals, most likely wheat (cf. Triticum), was identified. In the group of arboreal species the pollen of alder (Alnus), birch (Betula sect. Albae), and pine (Pinus) predominate. A lot of charcoal fragment particles were found at this same depth interval in the Ahb horizon.

It is obvious that the described composition of spore-pollen spectra does not reflect the modern type of vegetation which prevails in the investigated 
territory. Apparently, these spectra reflect the narrow-local conditions of the environment, where ferns and onagraceae grew in a limited area with a disturbed soil cover (possibly as a result of fires).

In the spore-pollen spectra of the sample from the Bhsb horizon (at a depth of 40-50 cm), wood species represented by the pollen of birch (Betula sect. Albae), alder (Alnus), and pine (Pinus) prevail. Also, several grains of lime (Tilia) and hazel (Corylus) pollen were found. The pollen of grasses is rare, and spore plants are represented by spores of ferns (Polypodiaceae) and sphagnum mosses (Sphagnum) in small amounts. It is possible that the prevalence of birch in the spore-pollen spectra of this sample is due to the reduction of native coniferous forests by man.

Thus, the data of phytolith and spore-pollen analyses correlate well with each other. In both cases, a small amount of spores and pollen is noted in almost all surface samples, which indicates anthropogenic disturbance of the original landscapes, primarily associated with the destruction of the Litter horizon. In both cases, a change in the tree layer from the indigenous coniferous forests to secondary small-leaved forests is recorded. It seems important that in the upper horizons of buried soils there are diagnostics of cultivated cereals - pollen and phytolith. This clearly indicates the plowing past of the studied archaeological site.

\section{Conclusions}

Investigations of the composition of the buried soil formed on the surface of the kame hill to which the medieval Izhora burial mound Kirsino 8 was tied showed that the original soil cover was represented by combinations of automorphic Entic Podzols (Lamellic, Arenic) and Albic Podzols (Lamellic, Arenic). These soils are also characteristic of modern biogeocenoses, which indicates a practically changeless trend of pedogenesis in the average time interval.

It was determined that during the construction of the mound and leveling of its surface the soil cover was scalped to a significant degree: almost completely (in the central part of the kame hill) to several $\mathrm{cm}$ and tens of $\mathrm{cm}$ (in the peripheral part of the mound). The degree of diagenetic changes in soils during the time of their burial ( $\sim 800$ years) was determined primarily in the reduction of the TOC content by dozens of times compared to surface soil.

Based on the data of phytolith and sporepollen analyses it is quite possible to reconstruct the following sequence of development of the territory. The original coniferous forest was cut down, partly burnt. Then the site with ash was plowed for cereal crops (slash-and-burn type of management). After a short time (3-5 years), when the fertility of the soil had decreased, the site was abandoned and began to overgrow with forest (from small-leaved species to coniferous). At this stage, the forest was rebuilt for burial mounds.

Because of their relative (up to $10 \mathrm{~m}$ ) elevation above the terrain surface which excludes ground swamping, the kame hills - composed mostly of sandy and water-permeable parent material - were a convenient place for the construction of barrow medieval burial grounds.

\section{Acknowledgements}

This study was supported by the Russian Science Foundation (Project No. 16-17-10280). Phytoliths analysis was supported by the Russian Science Foundation (Project No. 14-27-00133). The study was partially supported by a grant from St. Petersburg State University No. 18.40.68.2017. The authors are grateful to Darya K. Boudnik for improving English of this article. 


\section{References}

Cwynar, L.E., Burden, E. \& McAndrews, J.H., 1979. An inexpensive sieving method for concentrating pollen and spores from fine-grained sediments. Canadian Journal of Earth Sciences 16, 1115-1120. https://doi.org/10.1139/e79-097.

Engovatova A.V. \& Golyeva A.A., 2012. Anthropogenic soils in Yaroslavl (Central Russia): history, development, and landscape reconstruction. Quaternary International 265, 54-62. https://doi:10.1016/j.quaint.2012.02.039

Golyeva, A., 2001. Biomorphic analysis as a part of soil morphological investigations. Catena 43, 217-230. https://doi.org/10.1016/S0341-8162(00)00165-X

Golyeva, A., 2007. Various phytolith types as bearers of different kinds of ecological information. In: Madella, M. \& Zurro, D. (eds.), Plants, people and places. Recent studies in phytolith analysis. Oxbow books, pp. 196-201.

Golyeva, A.A. \& Aleksandrovskiy, A.L., 1999. The application of phytolith analysis for solving problems of soil genesis and evolution. Eurasian Soil Science 32, 884-891.

Golyeva A.A., Aleksandrovskiy, A.L. \& Tselishcheva, L.K., 1995. Phytolitic analysis of Holocene paleosols. Eurasian Soil Science 27, 46-56.

Grichuk, V.P. \& Zaklinskaya, E.D., 1948. The Analysis of Fossil Pollen and Spore and Using These Data in the Paleogeography. Geographis Publishing House, Moscow, 240 p. (in Russian)

Guidelines for soil description. Fourth edition, 2006. Food and Agriculture Organization of the United Nations, Rome, Italy, $97 \mathrm{p}$.

IUSS Working Group WRB, 2015. World Reference Base for Soil Resources 2014, International soil classification system for naming soils and creating legends for soil maps,
Update 2015. Food and Agriculture Organization of the United Nations, Rome, Italy, $192 \mathrm{p}$.

Kachinskiy, N.A., 1965. Soil physics, part 1. Higher Education Publishing House, Moscow, 321 p. (in Russian)

Kozlovskiy, F.I., 1977. Methods of salt regime assessment in soils. Methods of stationary studies of soils. Science Pulbishing House, Moscow, pp. 88-166. (in Russian)

Kupriyanova, L.A. \& Alyoshina, L.A., 1972. Pollen and Spores of Plants from the Flora of European Part of USSR, vol. 1. Acad. Sci. USSR, Komarov. Bot. Inst., Leningrad, 170 p. (in Russian)

Kupriyanova, L.A. \& Alyoshina, L.A., 1978. Pollen and Spores of Plants from the Flora of European Part of USSR. Acad. Sci. USSR, Komarov. Bot. Inst., Leningrad, 184 p. (in Russian)

Moore, P.D., Webb, J.A. \& Collinson, M.E., 1991. Pollen Analysis. Blackwell Scientific Publications, Oxford, 216 p.

Paleopedology Glossary, 1994. Paleopedology Commission Newsletter. Electronic resource, available from: http://fadr.msu.ru/inqua/nl-14/glossary.html.

Shishov, L.L., Komov, N.V. \& Rodin, A.S., 2001. Soil Cover and Land Resources of the Russian Federation. Moscow, 400 p. (in Russian)

Sorokin, P.E., 2006. Excavations of Izhora burial grounds in the Neva River Basin. Zapiski IIMK RAS 1, 94-111. (in Russian)

Sorokin, P.E., 2008. Izhora in the Middle Ages. On the origin and Early History. In: Ladoga and Ladoga Land in the Middle Ages. Saint Petersburg, pp. 177-215. (in Russian)

Vorobyova, L.A. (Ed.)., 2006. Theory and practice of chemical analyses of soils. GEOS Publishing House, Moscow, 400 p. (in Russian) 